\title{
PENGGUNAAN MEDIA GAMBAR UNTUK MENINGKATKAN PENGUASAAN VOCABULARY ANAK
}

\author{
${ }^{1}$ Nurul Ulfah Putri Utami, ${ }^{2}$ Taopik Rahman \\ Program Studi PG-PAUD Universitas Pendidikan Indonesia Kampus Tasikmalaya \\ Email: nurul.ulfah20@yahoo.com
}

(Received: Mei 2018; Accepted: Mei 2018; Published: Juni 2018)

\begin{abstract}
This study triggered by the lack of mastery of vocabulary in English language learning. It is based on interviews and learning activities of researchers at TK Pertiwi DWP Tasikmalaya on the activities of the implementation of the PPL UPI Tasikmalaya in 2017, as well as the data pre action before the research activities carried out which shows that there are still many students who do not abide by the minimum completeness criteria (KKM ). Low mastery of vocabulary students are not separated from the ineffectiveness of the media used and the ability of teachers to plan and implement teaching and learning. This study aims to determine the planning, implementation and improvement ofmastery of vocabulary children'sthrough the use of media images. Media image is a kind of learning media by using the image (pattern / graffiti a form) that is projected onto the twodimensional form. By using media images of children will obtain data about an object in full shape, appearance and the name of the object. So that the child will be faster remember a word well. This is certainly very suitable to be applied on English language learning. In this study the research method used was classroom action research (PTK) is adapted from the model Kemmis and Mc Taggart with three cycles. Subjects in this study is the researchers themselves and the children in group A2 TK Pertiwi DWP Tawang District of Tasikmalaya, amounting to 13 people. Data was collected by APKG and observation sheet. Based on the results obtained by an increase in the ability of teachers to create lesson plan reached $92.18 \%$, enhancements to the ability of teachers in implementing the learning reached $93.12 \%$ and themastery of vocabulary child'sof $92.3 \%$. In general the increase occurred after be applied using media images
\end{abstract}

Keyword: media, image, vocabulary

\begin{abstract}
ABSTRAK
Penelitian ini dilatar belakangi oleh rendahnya penguasan kosa kata pada pembelajaran bahasa inggris. Hal ini didasarkan pada hasil wawancara dan kegiatan belajar mengajar peneliti di TK Pertiwi DWP Kota Tasikmalaya pada kegiatan pelaksanaan PPL UPI Tasikmalaya tahun 2017, serta data hasil pra tindakan sebelum kegiatan penelitian dilaksanakan yang menunjukan bahwa masih banyak siswa yang tidak memenuhi nilai kriteria ketuntasan minimal (KKM). Rendahnya penguasaan vocabulary siswa tidak terlepas dari tidak efektifnya media yang digunakan dan kemampuan guru dalam merencanakan dan melaksanakan kegiatan belajar mengajar. Penelitian ini bertujuan untuk mengetahui perencanaan, pelaksanaan dan peningkatan penguasaan vocabulary anak melalui penggunaan media gambar. Media gambar adalah suatu jenis media pembelajaran dengan menggunakan gambar (pola/coretan suatu bentuk) yang diproyeksikan ke dalam bentuk 2 dimensi. Dengan menggunakan media gambar anak akan memperoleh data mengenai suatu benda secara lengkap baik bentuk, tampilan maupun nama benda tersebut. Sehingga anak akan lebih cepat mengingat suatu kata dengan baik. Hal ini tentunya sangat cocok diterapkan pada pembelajaran bahasa inggris. Pada penelitian ini metode penelitian yang digunakan adalah penelitian tindakan kelas (PTK) yang mengadaptasi dari model Kemmis dan Mc Taggart dengan tiga siklus. Subjek dalam penelitian ini adalah peneliti sendiri dan anak kelompok A2 TK Pertiwi DWP Kecamatan Tawang Kota Tasikmalaya yang berjumlah 13 orang. Pengumpulan data dilakukan dengan APKG dan lembar observasi. Berdasarkan hasil penelitian diperoleh peningkatan kemampuan guru dalam membuat rencana pelaksanaan pembelajaran mencapai $92,18 \%$, peningakatan kemampuan guru dalam melaksanakan pembelajaran mencapai $93,12 \%$ dan hasil penguasaan vocabulary anak mencapai 92,3\%. Secara umum peningkatan terjadi setelah diterapakan penggunaan media gambar.
\end{abstract}

Kata Kunci : media, gambar, vocabulary 


\section{PENDAHULUAN}

Diberlakukannya Undang-Undang No.20 tahun 2003 tentang sistem pendidikan nasional, berimbas pada penyelenggaraan pendidikan anak usia dini di berbagai daerah di Indonesia.. Maka sistem pendidikan di Indonesia sekarang terdiri dari pendidikan anak usia dini, pendidikan dasar, pendidikan menengah dan pendidikan tinggi yang semuanya merupakan kesatuan yang sistematik. Berkenaan dengan pendidikan bagi anak usia dini, menjadi sangat penting mengingat masa ini merupakan masa peletak dasar. Artinya potensi kecerdasan dan perilaku dasar anak akan terbentuk pada masa ini. Stimulasi bagi potensi kecerdasan dan pembentukan prilaku ini menjadi tugas bersama. Maka dari itu dalam pendidikan anak usia dini diselenggarakan kedalam beberapa jalur pendidikan yaitu, jalur pendidikan formal (TK, RA, dan sederajat), jalur pendidikan non formal (KB,TPA, dan sederajat) dan jalur pendidikan informal yaitu lingkungan keluarga.

Selain dari UU no 20 tahun 2003 pendidikan bagi anak usia dini diperkuat kembali dalam Peraturan Menteri Pendidikan dan Kebudayaan no 146 tahun 2013 pasal 5 ayat satu menyebutkan bahwa struktur kurikulum PAUD memuat, nilai agama dan moral, fisik motorik, kognitif, bahasa, sosial emosional, dan seni. Selanjutnya dalam ayat 5 dijelaskan kembali bahwa pengembangan bahasa sebagaimana dimaksud pada ayat (1) huruf d mencakup perwujudan suasana untuk berkembangnya kematangan bahasa dalam konteks bermain. Berdasarkan pada hal tersebut, maka baik adanya jika perkembangan bahasa distimulasi sejak dini. Termasuk dengan mengenalkan berbagai macam kosa kata dalam bahasa inggris.

Berkaitan dengan hal tersebut, untuk mempelajari bahasa Inggris akan lebih mudah apabila dilakukan sejak usia dini. Mengingat pada masa ini merupakan masa keemasan (Golden Age). Anak usia dini berada dalam masa keemasan di sepanjang rentang usia perkembangan manusia. Oleh karenanya, potensi kecerdasan anak perlu dioptimalkan dengan baik agar dapat menjadi bekal bagi kehidupannya dimasa yang akan datang. Seperti yang telah disinggung sebelumnya dalam Permendikbud 146 bahwa perkembangan bahasa harus berada dalam konteks bermain. Ini artinya dalam membelajarkan bahasa inggris kepada anak tidak semata-mata memberikan intruksi untuk menghapal. Namun pembelajarannya harus disampaikan dengan bentuk permainan. Sehingga anak akan merasa bahwa dia sedang belajar. Maka dari itu pembelajaran bahasa inggris harus disajikan semenarik dan seringan mungkin. Agar konten yang disampaikan pada anak tidak membuat anak menjadi stres dan enggan untuk belajar.

Namun kenyataannya dilapangan masih banyak dijumpai kekeliruan dalam pembelajaran bahasa Inggris di PAUD. Masih banyak PAUD yang kurang optimal dalam memberikan pengajaran Bahasa Inggris. Hal ini terlihat pada saat peneliti melakukan observasi ke beberapa sekolah. Tidak seperti pelajaran yang lain yang mendominasi setiap kegiatan belajar seperti matematika dan seni. Lain hal nya dengan Bahasa Inggris yang hanya terselip lewat beberapa lagu, itu pun kadang tidak koheren dengan tema yang sedang berlangsung. Sehingga anak hanya bisa menyanyikan lagu berbahasa inggris tersebut tanpa mengetahui arti yang terkandung dalam setiap kata nya. Kurangnya variasi dalam pembelajaran bahasa inggris tersebut akan mengakibatkan kurangnya kosa kata bahasa inggris anak dan pemahaman anak akan arti dari kata tersebut.

\section{KAJIAN PUSTAKA}

1. Media Gambar

1.1 Media Pembelajaran AUD

Media berasal dari bahasa latin yang berati medius. Kata media merupakan bentuk jamak dari kata medium yang berati perantara atau pengantar. Menurut Gerlach dan Ery (dalam 
Latifdkk, 2014, hlm. 150 ) bahwa media apabila di pahami secara garis besar adalah manusia, materi, atau kejadian yang membangun kondisi yang membuat siswa mampu memperoleh pengetahuan, keterampilan atau sikap. Sedangkan menurut Heinich dkk ( dalam Mursid, 2016, hlm. 40 ) mengemukakan istilah medium sebagai perantara yang mengantar informasi antara sumber dan penerima. Sedangkan menurut Yusufhadi Miarso (2004) Media adalah segala sesuatu yang digunakan untuk menyalurkan pesan, serta dapat merangsang pikiran perasaan, perhatian, dan kemauan belajar sehingga dapat mendorong terjadinya proses belajar yang disengaja, bertujuan dan terkendali. Contoh alat permainan, buku bacaan, audio visual aid, alat peraga, sciencekit, dll.

Media pembelajaran di klasifikasikan berdasarkan beberapa jenis. Hal ini berguna untuk mengetahui media mana yang cocok untuk digunakan dalam pembelajaran yang akan disajikan. Pengklasifikasian media berguna untuk menentukan media mana yang dipilih pada saat pembelajaran. Karena pada sejatinya, tidak semua media pembelajaran dapat membantu proses pembelajaran. Hal ini harus disesuaikan dengan kebutuhan di lapangan. Misalnya dalam pembelajaran anak usia dini, media yang dipilih harus sesuai dengan usia dan karakteristik anak, serta indikator, tema dan sub tema pembelajaran. Selain itu, pemilihan media juga harus didasarkan pada kegunaannya dalam menstimulasi kebutuhan perkembangan anak. Maka dari itu, guru harus mengetahui bahwa media pembelajaran sama penting nya dengan komponen pembelajaran yang lain. Apabila pemilihan media nya tidak tepat, maka hasilnya pun bisa berbeda dengan yang diharapkan. Setelah diklasifikasikan sesuai dengan media yang dibutuhkan, maka diperlukan pengelolaan atau manajemen terhadap media tersebut yang meliputi perencanaan, pengadaan, pemanfaatan, perawatan dan evaluasi.
Dalam tahapan pengadaan terbagi kedalam dua jenis yaitu pembuatan dan penggunaan yang sudah ada seperti membeli, sumbangan, atau dengan cara tukar pakai. Sedangkan dalam hal pembuatan harus memperhatikan beberapa hal tertentu seperti desain produk dan aspek-aspek yang perlu dicapai. Sepesti aspek edukatif, aspek teknis dan aspek estetika. Media yang digunakan pada pendidikan anak usia dini berbeda dengan media pada jenjang pendidikan yang lebih tinggi. Hal ini disesuaikan dengan karakteristik dan kebutuhan anak usia dini, maka dari itu berikut ini merupakan prosedur pengembangan media pembelajaran anak usia dini. Menurut Mursid (2016, hlm. 40) tujuan pendidikan pada dasarnya mengantarkan siswa menuju pada perubahan-perubahan tingkah laku baik intelektual, moral maupun sosial anak agar dapat hidup mandiri sebagai individu dan mahluk sosial. Media sebagai bagian dari komponen metodologi pembelajaran memiliki kedudukan yang sangat penting dalam mencapai tujuan pembelajaran secara efektif. Hal ini sejalan dengan pemikiran Latif, dkk (2014, hlm. 151) yang mengemukakan bahwa media dalam proses pembelajaran dapat mempertinggi proses belajar siswa dalam pembelajaran yang pada gilirannya diharapkan dapat mempertinggi hasil belajar yang dicapainya. Dalam pendidikan anak usia dini artinya media yang digunakan adalah sama artinya dengan media main anak. Segala bentuk media yang digunakan mampu untuk mengasah keterampilan anak dan memberikan pengetahuan bagi anak.

\subsection{Media Gambar}

Gambar merupakan suatu bentuk tertentu yang memiliki warna mencolok guna menarik perhatian dan minat anak. Media gambar termasuk jenis media visual yang tidak bergerak karena gambar ini dibuat dari karton dengan berbagai macam ukuran. Untuk membuat media lebih awet, karton bergambar tersebut akan dilaminasi dengan plastik laminasi. Ukuran yang berbeda ini bukan tanpa 
tujuan. Melainkan untuk memudahkan proses pembelajaran. Media gambar dibuat dengan dua ukuran, yaitu ukuran A4 dan ukuran A5. Ukuran A4 adalah media yang dipegang oleh guru guna menjelaskan materi, sedangkan ukuran A4 adalah media yang diberikan kepada anak, sehingga memudahkan anak mengamati secara langsung. Media gambar memilki banyak manfaat yaitu:

1) Bersifat konkret.

2) Mengatasi keterbatasan pengamatan.

3) Bernilai ekonomis.

4) Mudah digunakan.

Pada dasarnya pembelajaran anak usia dini adalah mengenalkan dari benda yang konkret ke abstrak. Karena pada hakikatnya anak masih belum bisa berpikir dari abstrak ke konkret. Oleh sebab itu dalam pembelajarannya akan lebih baik apa bila menghadirkan bentuk benda yang nyata. Namun, tidak mungkin bagi guru untuk mengahdirkan setiap benda nyata pada setiap pembelajaran karena ada beberapa benda yang tidak mungkin dapata dihadirkan dikelas. Seperti pada tema binatang buas, guru tidak mungkin membawa singa ke dalam kelas kecuali dengan diadakannya field trip ke kebung binatang. Dengan berbagai keterbatasan tersebut, maka penggunaan media gambar dapat mengatasi keterbatasan ruang dan waktu.

Untuk mengoptimalkan daya eksplor anak, maka dengan menggunakan media gambar dapat menyajikan gambar-gambar yang detail. Contohnya dalam mengamati daun, anak sepintas hanya akan melihat daun berdasarkan bentuk, warna, dan ruas tulang dalam daun. Namun dengan menggunakan gambar anak dapat melihat serat-serat daun dengan jelas berkat bantuan mikroskop yang hasilnya dicetak ke dalam bentuk gambar.

Media yang digunakan kepada anak tidak selalu harus mahal. Media gambar bernilai ekonomis karena dalam pengadaannya bisa dibuat sendiri oleh guru. Meskipun diluar sudah banyak dijual berbagai macam media gambar seperti flash card. Namun jika bisa membuat sendiri, tak ada salahnya untuk menghemat pengeluaran.

Mudah didapatkan. Karena pengadaannya bisa dengan cara dibeli ataupun dibuat sendiri oleh guru, maka media gambar sangat mudah untuk didapatkan. Sehingga guru tak akan kesulitan untuk mencari media gambar tersebut. Ukurannya yang bervariasi bisa disesuaikan dengan kebutuhan guru, sehingga dapat digunakan dengan mudah. Terlebih lagi apabila dibuat sendiri.

Meskipun memiliki banyak manfaat, namun tidak semua gambar dapat dijadikan sebagai media pembelajaran. Menurut latif, dkk (2014, hlm.153) menjelaskan bahwa ada beberapa syarat tentang gambar/foto yang baik agar bisa dijadikan media pembelajaran yaitu :

1) Autentik (jujur/sebenarnya);

2) Sederhana (poin-poin nya jelas);

3) Ukuran relatif;

4) Mengandung gerak atau perbuatan ( menunjukan objek dalam aktivitas tertentu );

5) Gambar atau foto karya siswa sendiri akan lebih baik;

6) Gambar hendaklah bagus dari sudut seni dan sesuai dengan tujuan pembelajaran yang ingin dicapai.

2. Pengusaan Vocabulary

2.1 Neurolinguistik

Golden age merupakan suatu masa pada rentang usia 0-8 tahun. Merupakan masa yang penting dalam setiap kehidupan manusia. Pernyataan tersebut bukan tanpa alasan. Terbukti dengan banyaknya temuan dan riset seputar anak usia dini dalam bidang neurosains. Seperti yang dikemukakan oleh Gardner menyatakan bahwa anak-anak pada lima tahun pertama selalu diwarnai dengan keberhasilan dalam belajar mengenai segala hal. 
Temuan yang dimaksudkan adalah fakta mengenai otak anak seperti yang dikemukakan oleh Suyadi $(2014,31)$ bahwa ketika anak lahir sel-sel otaknya mencapai 100 miliar, tetapi belum saling berhubungan kecuali hanya sedikit yaitu hanya sel-sel otak yang mengendalikan detak jantung, pernapasan, gerak refleks, pendengaran dan naluri hidup. Ketika anak memasuki usia 3 tahun, sel otak telah membentuk sekitar 1000 triliun jaringan koneksi/sinapsis. Sinaps-sinaps yang jarang digunakan akan mati, sedangkan yang sering digunakan akan semakin kuat dan permanen. Otak dan syaraf tulang belakang menyusun sistem syaraf pusat. Syaraf tulang belakang bekerja dimulai dari area batang otak, lalu ke tengah-tengah punggung yang dilindungi oleh struktur tulang belakang. Komunikasi dari pesan-pesan otak ke bagian tubuh yang lain berlangsung lewat tulang belakang dan sistem syaraf periferal (Otto, hlm 46: 2015). Sistem syaraf periferal melingkupi jalur syaraf yang menghubungkan syaraf tulang belakang ke seluruh bagian tubuh. Sistem syaraf ini menjalankan beberapa tugas termasuk dengan menciptakan bahasa.

Dalam hal pengembangan bahasa hubungan yang kompleks antara sifat dasar dan pengasuhan adalah bukti nyata dari suatu penelitian khusus tentang peran otak dalam pengembangan bahasa (Bergen \&Coscia, 2011). Hal ini terjadi karena pengasuhan dapat berpengaruh pada perkembangan bahasa anak. riset menunjukan bahwa anak yang diasuh oleh orangtua yang pasif maka akan menjadikan anak tersebut pasif juga. Sehingga akan berpengaruh pada pembendaharaan kata nya. Karena secara otomatis kata-kata yang di dengar oleh anak yang diasuh oleh orangtua yang pasif tidak sebanyak anak yang diasuh oleh orang tua yang aktif. Hal ini sejalan dengan pendapat Mutes (1973, hlm. 43) bahwa perawatan terbaik untuk bayi dan balita adalah bahwa diberikan oleh keluarga mereka sendiri di rumah mereka sendiri. Penelitian terhadap bayi telah mencatat bahwa aktivitas otak telah banyak terjadi di belahan kiri otak dari pada dibelahan kanan ketika bayi sedang mendengarkan suara ujaran (Hanh, 1987 in Santrock, 2001).

\subsection{Proses Pemerolehan Bahasa}

Menurut Iskandarwassid dan Sunendar ( 2015, hlm. 84) pemerolehan bahasa diartikan sebagai periode seorang individu memperoleh bahasa atau kosa kata baru.Bahasa didapatkan dengan sosialisasi. Artinya tidak mungkin terjadi pemerolehan bahasa tanpa sosialisasi. Rumah, sekolah dan lingkungan masyarakat adalah tempat dimana anak dapat bersosialisasi dan belajar bahasa. Pemerolehan bahasa didapatkan secara tidak sadar dan berorientasi pada pesan yang dimaksud.

Pematangan otak terjadi pada saat anak masih dalam kandungan. Janin akan tumbuh dan berkembang secara kompleks, termasuk di dalamnya perkembangan jalinan syaraf yang memproses penerimaan dan pembuatan bahasa. Disamping pematangan otak, hal penting bagi perkembangan bahasa adalah bahwa pematangan itu terjadi didalam lingkungan dimana bahasa digunakan dalam interaksi sosial. Menurut Piaget dan Inhelder (2010, 91) sejak akhir tahun kedua anak kalimat dua kata muncul, lalu kalimat utuh pendek tanpa konjungsi dan berikutnya penguasaan struktur tata bahasa setahap demi setahap. Untuk mengucapkan kalimat, meskipun hanya dua kata tentunya anak memerlukan pembendaharaan yang cukup. Maka dari itu pemerolehan bahasa tentunya diperoleh dari mulai mengumpulkan kata per kata.

Dalam perkembangan bahasa terdapat beberapa pola intraksi utama yang dapat memperluas perkembangan bahasa itu sendiri. Pola intraksi utama ini merupakan pola dasar dalam membangun komunikasi (Otto, 2015, hlm. 115). Terdapat dua komponen penting dalam pola intraksi ini, yaitu kontak mata dan perputaran komunikasi. Kontak mata diciptakan oleh orang dewasa dengan anak untuk menciptakan suatu fokus yang sama. 
Ketika kontak mata tidak terjalin dengan baik komunikasi akan terganggu atau bahkan tidak berjalan karena tidak adanya fokus yang jelas. Kontak mata biasanya diciptakan oleh penglihatan pertama orang dewasa terhadap anak atau dengan ucapan singkat untuk mendapat perhatian seperti "lihat".

Solso, dkk (2015, hlm.273) mengemukakan bahwa alasan yang menyebabkan kata-kata dan bahasa dipelajari secara mendalam dalam psikologi kognitif adalah bahwa struktur semantik memungkinkan kita mengidentifikasi jenis-jenis "benda" yang tersimpan dalam memori dan bagaimana "benda" yang tersimpan tersebut saling berhubungan dengan "benda" yang lain. Hal ini sejalan dengan pendapat Piaget (Tarigan, 2011, hlm. 14 ) bahasa adalah suatu sarana luar (outside agent) dalam perkembangan pikiran sang anak. Bahasa melayani sang anak dengan cara menerjemahkan lambang-lambang pribadi, struktur atau kemasyarakatan. Selanjutnya menurut Tarigan (2011, hlm.14 ) apabila sang anak tiba pada tahap pemahaman kata atau bahasa, maka dia harus mengasimilasikan kemudian mengakomodasikan tanda-tanda bahasa menjadi struktur-struktur lambangnya. Tetapi, jika dia menemui maknanya sendiri, maka penstrukturan lambang itu harus datang pertama sekali dan tidak disamarkan atau dibingungkan oleh struktur-struktur bahasa orang dewasa.

Intraksi secara lisan dengan anak harus dimulai sejak anak dilahirkan. Bayi cenderung lebih suka mendengar bunyi dari manusia dibandingkan dengan bunyi lain. Hal ini berlanjut hingga usia 4 bulan bayi lebih senang mendengarkan suara ibu nya. komunikasi yang dilakukan ibu dan bayi kelihatannya seperti komunikasi satu arah. Hal ini disebabkan karena bayi belum bisa membuat ujarannya sendiri. Padahal pada kenyataannya bayi dapat merespon komunikasi tersebut dengan gerak tubuh tertentu.

Bahasa yang didapatkan anak dari ibu ini lah yang seri disebut bahasa pertama anak. Bahasa pertama adalah bahasa yang pertama kali dikenal oleh anak. sedangkan bahasa keduanya adalah bahasa yang diperoleh bisa masih berada di lingkungan rumah ataupun lingkungan masyarakat dan lingkungan sekolah. Namun pada dasarnya masyarakat Indonesia sudah memperoleh dua bahasa sejak dini, yakni bahasa daerah dan bahasa Indonesia. Menurut Baker (Otto, 2015, hlm. 86) menjelaskan bahwa anak-anak yang memperoleh dua bahasa sebelum usia tiga tahun disebut dengan bilingualisme simultaneous. Sedangkan anak yang memperoleh bahasa kedua setelah usia tiga tahun disebut bilingualisme suksesif.

Menurut Iskandarwassid dan Sunendar (2015, hlm. 79) pemerolehan bahasa kedua merupakan sebuah aktivitas dengan dua dimensi. Kedua dimensi itu adalah belajar bahasa itu sendiri dan belajar segi lain melalui bahasa sebagai instrumennya. Ketika anakanak telah memperoleh dua bahasa, maka mereka telah mampu mencampurkan bahasa dalam intraksi komukatif yang sama. Baker (Otto, 2015, hlm. 87) mengemukakan contoh dimana anak terlihat mencampuradukan dua bahasa ( dikenal dengan nama code mixing, atau language mixing ) secara sederhana menunjukan penggunaan dua bahasa oleh orangtuanya. Hal ini menunjukan bahwa anak ingin menyampaikan suatu pesan namun pengetahuan dalam bahasa kedua belum cukup untuk mengekspresikan pesan tersebut. Keuntungan dari mempelajari bahasa kedua ini adalah seperti yang dikemukakan oleh Ben Zeev, dkk (Otto, 2015, hlm. 88) anak-anak yang telah memperoleh tingkat kepasihan dalam dua bahasa telah digambarkan memperoleh kemampuan bahasa yang meningkat, seperti : tingkat pemahaman metalinguistik yang lebih tinggi, pemahaman susunan bahasa yang lebih luas dan lebih awal, perspektif yang lebih luas dan kemampuan sosial yang lebih.

Seperti telah disinguung sebelumnya, bahwa masyarakat Indonesia pada dasarnya adalah 
bilingualisme. Maka dapat disimpulakn bahwa bahasa pertamanya atau bahasa ibu nya adalah bahasa daerah dan bahasa Indonesia sendiri sebagai bahasa nasional. Sehingga bahasa keduanya adalah bahasa asing seperti bahasa Inggris. Kesulitan yang akan dihadapi oleh anak dalam pembelajaran bahasa inggris adalah berbeda nya cara pembacaan (pronunciation) dengan tulisan. Menurut Liamina dan Gagua (1972, hlm 207) masalah pembentukan pengucapan yang benar dari suara oleh anak-anak pada waktu yang tepat masih menjadi masalah. Perlunya pendidikan awal (5-6 tahun) dalam tata bahasa dan bahasa asing menuntut bahwa proses pembentukan pengucapan yang benar akan selesai pada usia ini.

Mampunya anak menguasai berbagai bahasa pada usia dini semakin memperkuat bahwa ada baiknya memperkenalkan bahasa inggris kepada anak. Namun agar dalam pengajarannya berjalan dengan baik maka Krashen (Otto, 2015, hlm. 93) merekomendasikan agar guru dalam mempelajarkan bahasa kedua menyediakan input yang dapat dipahami dengan menggabungkan strategi-strategi berikut dikelas yaitu menanamkan bahasa kedua dalam konteks melalui gambar, realita dan gerakan, memodifikasi ujaran yang disampaikan pada murid dengan menggunakan bahasa yang lebih pelan dan tidak terlalu kompleks, mengatur kurikulum tidak berdasarkan susunan tata bahasa tetapi berdasarkan aktivitas yang kaya bahasa seperti permainan, menyelesaikan masalah dan mengadakan percobaan, mendorong tetapi tidak memaksa anak untuk berbicara, menunda pelajaran tata bahasa yang eksplisit dan formal.

Maka tak ada salahnya memperkenalkan bahasa inggris sebagai bahasa kedua selama dalam pelaksanaannya tidak dipaksakan. Dalam memperkenalkan bahasa inggris kepada anak dapat dimulai dengan memperkenalkan kosakata terlebih dahulu. Kosakata itu pun tidak boleh sembarangan, harus bersifat kontekstual agar mudah dipahami oleh anak. Menurut Hasan (2013, hlm. 33) otak yang belum matang rentang terhadap trauma. Karena hal tersebut, maka dalam memperkenalkan bahasa inggris guru harus sabar dan tidak memaksa.

\subsection{Kosa Kata}

Sejak dalam kandungan, janin sudah dapat mendengar suara (fonem) dari lingkungan sekitar. Pasca natal anak mulai mengenali suara yang selalu di dengarnya dalam kandungan, seperti suara ibunya. Kemudian mulai untuk mengucapkan kembali dengan bergumam. Karena pada dasarnya kesempatan untuk mengenalkan bahasa pada anak sudah terbuka sejak anak berusia 2 bulan sampai dengan 5 tahun. Namun area bahasa pada otak anak mulai benar benar aktif pada usia 18 sampai 20 bulan.

Menurut Suyadi (2014, hlm.105) pada usia 1820 bulan bayi dapat belajar secara alamiah 10 kata atau lebih perhari. Pada usia 3 tahun, anak rata-rata telah menguasai 900 kata. Selanjutnya, pada usia 5 tahun anak-anak telah mampu menguasai 2.500 hingga 3.000 kata.

Sedangkan menurut Baddeley ( Solso, dkk, 2007, hlm. 273 ) mengungkapkan bahwa jumlah kata-kata yang maknanya diketahui oleh seseorang berkisar antara 20.000 hingga 40.000 kata dan memori rekognisi bahkan berjumlah jauh lebih besar dari angka tersebut. Tanpa disadari sebenarnya setiap guru ikut terlibat dalam proses penguasaan kosakata anak. Setiap kali guru berbicara dengan anak, secara tidak langsung guru sedang mengajarkan kosakata baru pada anak. Kosa kata yang dikuasai oleh anak pada dasarnya adalah berupa kosa kata dasar (basic vocabulary).

Pembelajaran kosakata haruslah bersifat enkulturasi. Menurut Suyono (2016, hlm. 135) enkulturasi adalah suatu proses dimana seseorang belajar tentang sesuatu yang diperlukan oleh budaya yang mengelilingi kehidupannya. Hal ini dapat memudahkan 
anak untuk mengingat kosakata yang diajarkan kepadanya. Pada intinya tujuan utama dari pengajaran kosakata adalah untuk mengembangkan minat anak pada kata-kata. Keterampilan anak dalam memepelajari kosakata dengan cara anak "membaca" gambar-gambar, mempertimbangkan kata-kata dan berpikir secara kritis. Karena pada dasarnya anak memiliki rasa ingin tahu yang tinggi, maka hal ini mempermudah anak memperkaya kosakata nya.

\section{METODE PENELITIAN}

Metode penelitian yang digunakan adalah Penelitian Tindakan Kelas. Bentuk dari Penelitian Tindakan Kelas ini adalah PTk KolaboratiParsipatoris. Hal ini bermakna bahwa penelitian tindakan kelas ini merupakan penelitian yang mempunyai sifat kerja sama antara peneliti dan peneliti mitra (guru wali kelas). Penelitian tindakan kelas menurut model Kemmis \& Taggart ini dilaksanakan dalam bentuk proses pegkajian bersiklus yang terdiri dari tiga tahap yaitu: (a) Perencanaan (planning); (b) Tindakan dan pengamatan (action \& bservation); serta (c) refleksi (reflection).

Penelitian dilaksanakan di TK Pertiwi DWP yang berada pada lingkup UPTD Pendidikan Kecamatan Tawang Kota Tasikmalaya pada semester dua Tahun ajaran 2016/2017. Subjek penelitian pada penelitian ini adalah guru (peneliti) dan siswa kelompok A2 TK Pertiwi DWP Kecamatan Tawang Kota Tasikmalaya yang berjumlah 13 siswa terdiri dari 7 orang siswa laki-laki dan 6 orang siswa perempuan. Dalam penelitian ini, teknik yang digunakan untuk mengambil sampel yaitu dengan menggunakan teknik sampling jenuh atau saturation Sampling. Hal ini berdasarkan pada pertimbangan sedikitnya jumlah sampel pada populasi tersebut. Instrumen yang digunakan yaitu berupa alat penilaian kemampuan guru dalam merencanakan pembelajaran dengan menggunakan media gambar (APKG I), alat penilaian kemampuan guru dalam melaksanakan pembelajaran dengan menggunakan media gambar (APKG II) dan alat penilaian penguasaan vocabulary anak.

\section{HASIL DAN PEMBAHASAN}

Setelah menyelesaikan tiga siklus dengan berbagai hal yang terjadi didalamnya, penelti bersama observer melakukan refleksi akhir untuk mengevaluasi keseluruhan tindakan selama penelitian berlangsung, mulai dari siklus I hingga siklus III. Peneliti dan observer sepakat bahwa penggunaan media gambar untuk meningkatkan penguasaan vocabulary anak di TK Pertiwi DWP Kota Tasikmalaya dapat dilaksanakan dengan baik. Termasuk didalamnya perbaikan kualitas perencanaan, pelaksanaan pembelajaran dan hasil penguasaan vocabulary anak telah tercapai dengan baik.

Hal ini ditunjukan dengan adanya peningkatan hasil akhir data pada setiap siklus. Berikut peneliti tampilkan hasil evaluasi keseluruhan siklus:

\section{Peningkatan Kemampuan Guru Menyusun Rencana Pembelajaran}

Kemampuan guru dalam menyusun rencana pelaksanaan pembelajaran pada siklus I telah mencapai indikator keberhasilan dengan persentase $76,56 \%$, namun demi memperbaiki bagian yang perlu diperbaiki maka peneliti melakukan refleksi dan konsultasi dengan observer dan dosen pembimbing. Sehubungan dengan hal tersebut, maka pada siklus II kemampuan guru dalam merencanakan pembelajaran mengalami peningkatan yang sangat signifikan dengan persentase 90,62\% .

Untuk lebih memantapkan kemampuan guru dalam menyusun rencana pembelajaran, maka berdasarkan hasil refleksi pada siklus II akhirnya peneliti dan observer sepakat untuk melanjutkan ke siklus III. Hasil penialaian kemampuan guru dalam merencanakan 
rencana pembelajaran pada siklus III tidak meningkat pesat. Karena pada dasarnya hasil pada siklus II pun sudah sangat baik. Persentase hasil penilaian pada siklus III yaitu $92,12 \%$. Berikut merupakan tabel peningkatan kemampuan guru dalam menyusun rencana pembelajaran:

\begin{tabular}{|c|c|c|c|}
\hline No & Siklus & $\begin{array}{c}\text { Perolehan } \\
\text { Nilai }\end{array}$ & $\begin{array}{c}\text { Margin } \\
\text { dari } \\
\text { Siklus I- } \\
\text { III }\end{array}$ \\
\hline 1 & $\mathrm{I}$ & $76,56 \%$ & \multirow{3}{*}{$15,62 \%$} \\
\hline 2 & II & $90,62 \%$ & \\
\hline 3 & III & $92,18 \%$ & \\
\hline
\end{tabular}

Tabel 1.1

Hasil Penilaian Kemampuan Guru Menyusun Rencana Pembelajaran Siklus I-III

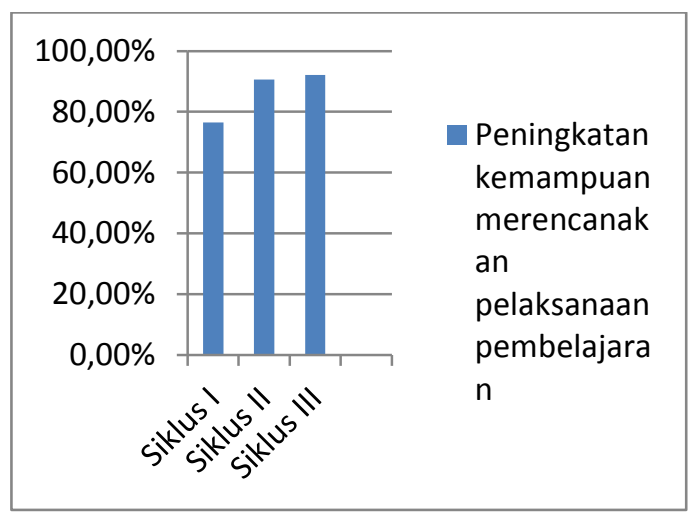

Grafik 1.1

Hasil Penilaian Kemampuan

Guru Menyusun Rencana Pembelajaran Siklus I-III

Berdasarkan pada tabel 4.18 dan grafik 4.1, maka pencapaian peningkatan kemampuan guru dalam merencanakan pelaksanaan pembelajaran menggunakan media gambar sudah baik. Hal ini diperkuat dengan data di siklus III mencapai persentase $92,18 \%$.

\section{Peningkatan Kemampuan Guru \\ Melaksanakan Pembelajaran}

Kemampuan guru dalam melaksanakan pembelajaran menggunakan media gambar mengalami peningkatan pada setiap siklusnya. Hal ini terjadi atas rkritik dan saran yang baim dari observer dan juga dukungan literatur. Peningkatan guru dalam melaksanakan pembelajaran ditunjukan pada tabel 4.19 dan grafik 4.2 sebagai berikut :

Tabel 2.1

Hasil Penilaian Kemampuan Guru Melaksanakan Proses Pembelajaran Siklus I-III

\begin{tabular}{|c|c|c|c|}
\hline $\begin{array}{l}\mathrm{N} \\
\mathrm{O}\end{array}$ & $\begin{array}{c}\text { Siklu } \\
\text { s }\end{array}$ & $\begin{array}{c}\text { Peroleha } \\
\text { n Nilai }\end{array}$ & $\begin{array}{c}\text { Margi } \\
\text { n dari } \\
\text { Siklus } \\
\text { I-III }\end{array}$ \\
\hline 1 & I & $80,62 \%$ & \\
\hline 2 & II & $87,5 \%$ & $12,5 \%$ \\
\hline 3 & III & $93,12 \%$ & \\
\hline
\end{tabular}

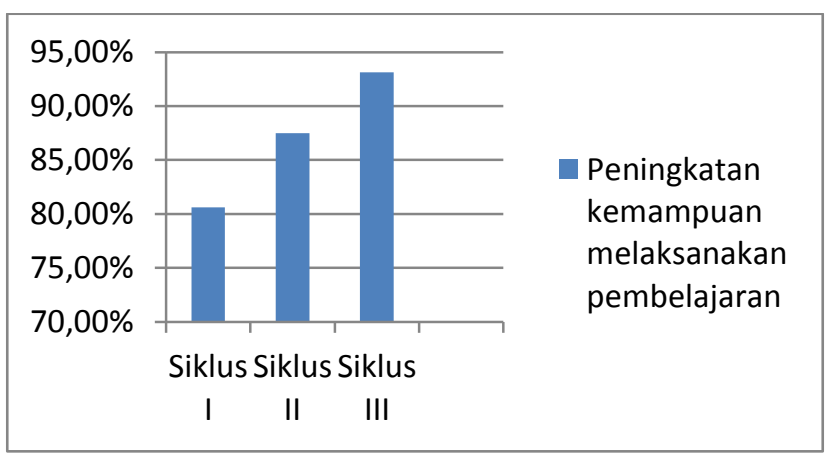

Grafik 2.1

Hasil Penilaian Kemampuan Guru Melaksanakan Proses Pembelajaran Siklus I-III

Peningkatan kemampuan guru dalam melaksanakan pembelajaran dicapai lebih awal, yakni mencapai persentase 80,62 \%. Meskipun begitu masih ada beberapa hal yang perlu diperbaiki terkait dengan rendahnya hasil penguasaan vocabulary anak. peneliti dan observer menduga bahwa kurangnya penguasaan anak akibat dari belum begitu baiknya keterampilan menjelaskan guru. Maka dari itu peneliti dan observer sepakat untuk memperbaikinya di siklus II.

Setelah siklus II dilaksanakan terjadi peningkatan sebesar $6,88 \%$. Dengan persentase hasil penilaian mencapai $87,5 \%$. Hal ini berkat rekomendasi dari observer pada refleksi siklus I. Kemudian nilai nya semakin 
meningkat di siklus III hingga mencapai 93,12 $\%$. Hasil akhir perolehan peningkatan guru melaksanakan pembelajaran dari siklus I sampai siklus III sebesar 15,62\%.

\section{Peningkatan Penguasaan Vocabulary}

Peningkatan penguasaan vocabulary juga mengalami peningkatan pada setiap siklusnya, hal ini merupakan tanda positif penggunaan media di TK Pertiwi DWP Kota Tasikmalaya. Data mengenai peningkatan penguasaan vocabulary disajikan pada tabel dan grafik berikut ini:

Tabel 3.1

Hasil Penilaian Penguasaan Vocabulary Siklus I- Siklus III

\begin{tabular}{|c|c|c|c|c|}
\hline \multirow[b]{2}{*}{ No } & \multirow[b]{2}{*}{ Nama Siswa } & \multicolumn{3}{|c|}{ Skor } \\
\hline & & Siklus I & Siklus II & Siklus III \\
\hline 1. & S-1 & 56 & 75 & 81 \\
\hline 2. & S-2 & 37 & 56 & 68 \\
\hline 3. & S-3 & 43 & 62 & 75 \\
\hline 4. & S-4 & 37 & 62 & 75 \\
\hline 5. & S-5 & 50 & 75 & 87 \\
\hline 6. & S-6 & 43 & 75 & 87 \\
\hline 7. & S-7 & 31 & 93 & 100 \\
\hline 8. & S-8 & 81 & 93 & 100 \\
\hline 9. & S-9 & 81 & 75 & 81 \\
\hline 10. & S-10 & 50 & 81 & 87 \\
\hline 11. & S-11 & 75 & 87 & 93 \\
\hline 12. & S-12 & 75 & 87 & 93 \\
\hline 13. & S-13 & 37 & 75 & 81 \\
\hline & $\Sigma$ Nilai & 696 & 996 & 1108 \\
\hline & Rata-rata & 53,53 & 76,61 & 85,23 \\
\hline
\end{tabular}

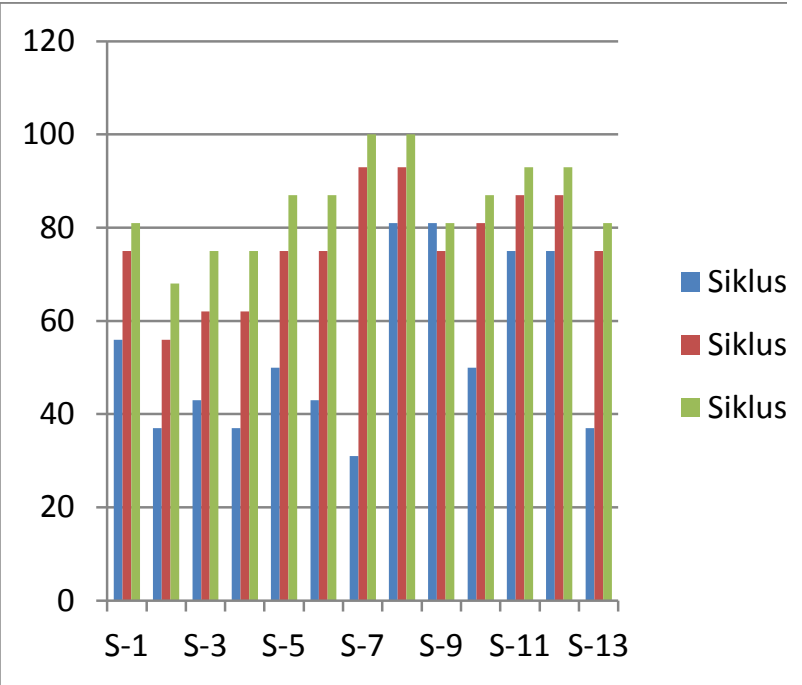

Grafik 3.1

Hasil Penilaian Penguasaan Vocabulary Siklus I- Siklus III
Data pada tabel 4.21 dan grafik 4.3 menjelaskan bahwa siswa yang memperoleh nilai < 75 pada siklus I sebanyak 9 siswa dengan persentase $69,23 \%$, pada siklus II berkurang menjadi 3 siswa dengan persentase 23,07\% dan pada siklus kembali berkurang menjadi 1 siswa dengan persentase 7,69\%. Sedangkan siswa yang memperoleh nilai $>75$ pada siklus I sebanyak 4 siswa dengan persentase $30,76 \%$, kemudian jumlahnya meningkat pesat pada siklus II sebanyak 10 dengan persentase 76,92. Pada siklus II indikator keberhasilan penguasaan vocabulary yakni $75 \%$ siswa memperoleh nilai $>75$ sudah diperoleh, namun untuk lebih memperkuat data maka dilanjutkan dengan siklus III dan siswa yang memperoleh nilai $>75$ sebanyak 12 siswa dengan persentase $92,3 \%$.

Dengan mencermati perkembangan yang terjadi pada setiap siklus dan divisualisasikan dalam tabel dan grafik diatas, diperoleh informasi bahwa penguasaan vocabulary dengan bantuan media gambar sudah mencapai hasil baik. Hal ini dibuktikan dengan data yang didapat dari siklus I sampai III terjadi peningkatan yang memuaskan.

Đari-seluruh proses dan hasil yang didapat selama pelaksanaan tindakan penelitian, peneliti dan observer meyakini bahwa kegiatan penelitian dengan menggunakan media gambar di TK Pertiwi DWP Kota Tasikmalaya dengan tema hewan peliharaan, sub tema kucing telah meningkatkan kemampuan guru dalam merencanakan dan melaksanakan pembelajaran serta meningkatkan penguasaan vocabulary anak dengan perolehan hasil yang memuaskan.

\section{KESIMPULAN DAN SARAN}

Pada perencanaan sebelum tindakan terdapat kekurangan dalam penggunaan media pembelajaran yang kaku dan tidak efektif. Namun terjadi perubahan pada penggunaan media pembelajaran pada siklus I. Pada siklus I 
skor yang didapatkan mencapai 76,56 \%, artinya skor ini telah melebihi dari skor yang ditentukan dalam indikator keberhasilan. Namun demikian ada beberapa aspek yang perlu diperbaiki. Maka guru berusaha untuk memperbaikinya pada siklus II. Setelah dilakukan perbaikan, skor pada siklus II mengalami peningkatan hingga 90,62 \%, artinya terjadi peningkatan sebesar 14,06\%. Meskipun begitu, tetap ada perbaikan pada pelaksanaan perencanaan siklus III. Pada siklus III skor meningkat, namun tidak begitu pesat yaitu sebesar 92,18\%. Karena pada siklus II skor yang di dapatkan memang sudah sangat baik.

Pada pelaksanaan, peneliti dibantu oleh peneliti mitra, pembelajaran sebelum tindakan terpusat pada guru dalam menggunakan media dalam pembelajaran bahasa inggris yang kurang membangkitkan semangat siswa. Setelah digunakan media berupa gambar kemudian dilengkapi dengan demonstrasi dan tanya jawab pada tema hewan peliharaan sub tema kucing, membuat siswa antusias dan semangat dalam mengkomunikasikan kembali apa yang mereka ketahui. Proses pelaksanaan pembelajaran pada setiap siklus mengalami peningkatan. Ini tidak terlepas dari saran dan kritik dari peneliti mitra ketika melakukan refleksi dengan peneliti. Pada siklus I skor yang dicapai sudah memenuhi indikator keberhasilan yaitu 80,62, namun perbaikan tetap ada. Terlebih lagi terkait keterampilan mengajar guru. Kemudian setelah dilakukan perbaikan, hasilnya kembali meningkat hingga mencapai skor 87,5. Dan pada siklus III pun kembali mengalami peningkatan sebesar 93,12. Hasil siklus III ini sebagai penguat dari hasilhasil sebelumnya.

Hasil penguasaan vocabulary pada siklus I memperoleh hasil yang kurang memuaskan yaitu dengan perolehan skor 53,84\% , sehingga peneliti dan observer memfokuskan pada pengelolaan kelas dalam hal keterampilan menjelaskan guru pada siklus II. Setelah dilakukan siklus II, akhirnya hasil penguasaan vocabulary anak meningkat pesat menjadi 76,69 \% . Hal ini karena saran dari observer pada refleksi siklus I. Kemudian hasilnya lebih meningkat lagi pada siklus III yakni mencapai skor $85,57 \%$.

Berdasarkan paparan simpulan diatas, dalam rangka perbaikan tindakan selanjutnya, maka berikut peneliti sampaikan rekomendasi terkait penelitian yang telah dilaksanakan. Adapun rekomendsainya adalah sebagai berikut yaitu bagi guru yang akan melaksanakan pembelajaran dikelas, penggunaan media gambar membutuhkan pengelolaan kelas dan waktu yang baik untuk optimalisasi pelaksanaanya. Sehingga diperlukan perencanaan yang baik agar anak senantiasa antusias dalam mengikuti pembelajaran dan penggunaan waktu dalam pembelajaran lebih efektif, anak sangat antusias untuk mendapatkan penghargaan dari guru berupa reward. Hal ini juga efektif dalam menumbuhkan minat anak. Namun perlu diingat bahwa kompetisi itu memang penting. Namun kerjasama juga penting. Sehingga pemberian reward hanya dilakukan pada saatsaat tertentu saja dan bagi peneliti selanjutnya harus diperhatikan dalam melaksanakan penelitian tindakan kelas, teknik pengumpulan data dan waktu yang akan dipakai dalam penelitian harus dipersiapkan dengan lebih matang.

\section{UCAPAN TERIMAKASIH}

Kepada yang terhormat dan terkasih. Terimakasih atas segala cinta dan motivasi yang tak kunjung padam. Dan terimakasih atas segala doa yang telah dipanjatkan dengan penuh ketulusan. Penulis mengucapkan terima kasih kepada, bapak Dr. Nandang Rusmana, M.Pd selaku Direktur Universitas Pendidikan Indonesia (UPI) Kampus Tasikmalaya, ibu Dr Hj. Epon Nur'aeni L.M,Pd selaku wakil direktur Universitas Pendidikan Indonesia (UPI) Kampus Tasikmalaya, bapak Drs. Edi Hendri Mulyana, M.Pd., selaku ketua Program Studi S-1 
PGPAUD Universitas Pendidikan Indonesia (UPI) Kampus Tasikmalaya, bapak Drs.Yusuf Suryana, M.Pd., bapak Taopik Rahman, M.Pd., seluruh Dosen Program S-1 PGPAUD, suami tercinta, abang Zakaria Al Harun, ibunda, Mamih Linda dan ayahanda Apih Empep serta keluarga tercinta, ibu Hj.Yeti Nuryati M, M.Pd selaku kepala sekolah TK Pertiwi DWP Kota Tasikmalaya beserta guru dan staf TK Pertiwi DWP Kota Tasikmalaya. ibu Hj.Enok Elis Lismawati, S.Pd.I Guru pamong kelompok A2 TK Pertiwi DWP sekaligus sebagai peneliti mitra, dan teman-teman seperjuangan PGPAUD 2013.

\section{DAFTAR PUSTAKA}

Arikunto, S. (2010). Prosedur Penelitian Suatu Pendekatan Praktik. Jakarta : Rineka Cipta

Departemen Pendidikan Nasional.(2003). Undang-undang UU Nomor 20 Tahun 2003 tentang Sistem Pendidikan Nasional. Jakarta: Depdiknas

Devi, Ferista.(2013). Permainan Kartu Acak untuk Meningkatkan Kosa Kata Anak Kelompok B TK Negeri Pembina I Kota Malang. Skripsi UM. [Tidak Diterbitkan]

Hasan, Maimunah.(2013). Pendidikan Anak Usia Dini. Jogjakarta : DIVA Press

Hurlock, Elizabeth B. (1978). Perkembangan Anak Jilid I. (Child Development). Jakarta : Erlangga

Iskandarassid. Dadang Sunendar.(2015). Strategi Pembelajaran Bahasa. Bandung: PT Remaja Rosdakarya

Kunandar.(2013). Langkah Mudah Penelitian Tindakan kelas. Depok: Kharisma Putra Offset

Latif, Mukhtar. Zukhairina. Rita Zubaidah. Muhamad Afandi.(2014). Orientasi Baru Pendidikan Anak Usia Dini: Teori dan Aplikasi. Jakarta: Prenadamedia Group
Liamina, G.M. N.I. Gagua.(1971). Speech Reaction In Children In The Third Year Of Life. Day Care and Early Education, 1. Hlm.21-35

Liamina, G.M. N.I. Gagua.(1972). On The Development Of Proper Pronunciation In Children Fromone.Early Child Developmentand Care, 1, hlm.207-22

Mauluddin, Ilham.(2014). Penerapan Metode Mind Map Untuk Meningkatkan Hasil Belajar Siswa Sekolah Dasar Melalui Pembelajaran Tematik. Skripsi UPI Tasikmalaya. [Tidak Diterbitkan]

Miarso, Yusufhadi.(2010). Menyemai Benih Teknologi Pendidikan. Bandung : Prenada Media Group

Modul PLPG PAUD.(2013). Media, TIK dan Pengelolaan Lingkungan Belajar. Bandung: PLPG PAUD

Mulyasa.(2007). Menjadi Guru Profesional menciptakan Pembelajaran Kreatif dan Menyenangkan. Bandung : PT Remaja Rosdakarya

Mursid.(2016).Pengembangan Pembelajaran PAUD. Bandung: PT Remaja Rosdakarya

Mutes, Barbara. (1973). Infants and Toddler. Day Care and Early Education, hlm. 143

Otto, Beverly.(2015). Language Development in Early Chilhood:Third Edition. Jakarta: Prenadamedia Group

Piaget, Jean. Barbel Inhelder.(2000). The Psychology of The Child. New York : Basic Books. Offset.

Peraturan Menteri Pendidikan dan kebudayaan.(2013). Undang-undang $U U$ Nomor 146 Tahun 2013 Tentang Kurikulum PAUD. Jakarta: Permendikbud 
Solso, Robert L. Otto H.Maclin. M.Kimberly Maclin.(2008). Cognitive Psycology.

Jakarta: Penerbit Erlangga.

Sugiyono. (2010). Metode Penelitian Kuantitatif, Kualitatif dan $R \& D$. Bandung : Alfabeta

Sujiono, Yuliani Nurani.(2013). Konsep Dasar Pendidikan Anak Usia Dini. Jakarta : PT Indeks

Suyadi.(2014). Teori Pembelajaran Anak Usia Dini Dalam Kajian Neurosains. Bandung: PT. Remaja Rosdakarya Offset

Tarigan, Henry Guntur.(2011). Pengajaran Kosakata. Bandung: Percetakan Angkasa

Suyono. Hariyanto.(2016). Belajar dan Pembelajaran: Teori dan Konsep Dasar. Bandung: PT Remaja Rosdakarya 